\title{
A new inventory for fishes of headwater streams from the rio das Cinzas and rio Itararé basins, rio Paranapanema system, Paraná, Brazil
}

\author{
Augusto Frota ${ }^{1,2 *}$, Renata Rúbia Ota ${ }^{1,2}$, Gabriel de Carvalho Deprá ${ }^{1,2}$, Maria Julia Mileo Ganassin ${ }^{2} \&$ \\ Weferson Júnio da Graça ${ }^{1,2,3,4}$ \\ ${ }^{1}$ Universidade Estadual de Maringá, Coleção Ictiológica do Núcleo de Pesquisas em Limnologia, Ictiologia e \\ Aquicultura, Av. Colombo, 5790. CEP 87020-900. Maringá, PR, Brasil. \\ ${ }^{2}$ Universidade Estadual de Maringá, Programa de Pós-Graduação em Ecologia de Ambientes Aquáticos \\ Continentais, Av. Colombo, 5790. CEP 87020-900. Maringá, PR, Brasil. \\ ${ }^{3}$ Universidade Estadual de Maringá, Programa de Pós-Graduação em Biologia Comparada, \\ Av. Colombo, 5790. CEP 87020-900. Maringá, PR, Brasil. \\ ${ }^{4}$ Universidade Estadual de Maringá, Centro de Ciências Biológicas, Departamento de Biologia e Núcleo de \\ Pesquisas em Limnologia, Ictiologia e Aquicultura, Av. Colombo, 5790. CEP 87020-900. Maringá, PR, Brasil. \\ *Corresponding author: Augusto Frota, e-mail: frota.augusto@gmail.com
}

FROTA, A., OTA, R. R., DEPRÁ, G. C., GANASSIN, M. J. M., DA GRAÇA, W. J. A new inventory for fishes of headwater streams from the rio das Cinzas and rio Itararé basins, rio Paranapanema system, Paraná, Brazil. Biota Neotropica. 20(1): e20190833. http://dx.doi.org/10.1590/1676-0611-BN-2019-0833

\begin{abstract}
The rio das Cinzas and rio Itararé basins are important tributaries of the rio Paranapanema, a major left-bank tributary of the upper rio Paraná basin. The upper reaches of both drainages intersect the northern portion of the APA Escarpa Devoniana (Devonian Escarpment Environment Protection Area, EPA), an area considered crucial for the preservation of biodiversity. This study aimed to provide an ichthyofaunistic inventory for headwater streams of the rio das Cinzas and rio Itarare basins, both within and off of the borders of the EPA, increasing the knowledge about the species already known from streams in the rio Paranapanema system. We found 32 fish species, representing five orders and 12 families. Siluriformes was the richest order followed by Characiformes. Ten species presented high abundance of sampled individuals, contributing with $85.0 \%$ of all specimens. Most species were classified as occasional (captured in less than $25 \%$ of the samples) and only two species were classified as constant (captured in more than $50 \%$ of samples), which may reflect the altitudinal gradient. We did not record any introduced species in the sampled streams, reinforcing the need of, at least, maintaining the original area of the EPA. We expanded the geographic distribution of Astyanax bifasciatus to the upper rio Paraná system, confirming the cases of faunal exchange among several drainage systems in the limits of the Ponta Grossa Arch. Finally, we identified three putatively undescribed species that show a large biodiversity knowledge shortfall for the region studied.
\end{abstract}

Keywords: Altitudinal gradient, Devonian Escarpment, faunal exchange, upper rio Paraná.

\section{Um novo inventário para peixes de riachos de cabeceira das bacias dos rio das Cinzas e rio Itararé, sistema do rio Paranapanema, Paraná, Brasil}

Resumo: As bacias do rio das Cinzas e do rio Itararé são afluentes importantes do rio Paranapanema, um dos principais afluentes da margem esquerda do alto rio Paraná. Os trechos superiores de ambas as drenagens interceptam a porção norte da Área de Proteção Ambiental (APA) da Escarpa Devoniana, uma área considerada crucial para a preservação da biodiversidade. Este trabalho teve como objetivo fornecer um inventário ictiofaunístico para riachos de cabeceira das bacias do rio das Cinzas e do rio Itararé, dentro e fora das fronteiras da APA, aumentando o conhecimento sobre as espécies já conhecidas dos riachos do rio Paranapanema. Encontramos 32 espécies de peixes, representando cinco ordens e 12 famílias. Siluriformes foi a ordem mais rica seguida por Characiformes. Dez espécies apresentaram alta abundância de indivíduos amostrados, contribuindo com $85,0 \%$ de todos os espécimes. A maioria das espécies foi classificada como ocasional (capturada em menos de 25\% das amostras) e apenas duas espécies foram classificadas como constantes (capturadas em mais de $50 \%$ das amostras), o que pode refletir o gradiente altitudinal. Não registramos nenhuma espécie introduzida nos riachos amostrados, reforçando a necessidade de, pelo menos, manter a área original do APA. Expandimos a distribuição geográfica de Astyanax bifasciatus para o sistema do alto rio Paraná, confirmando os casos de intercâmbio faunístico entre vários sistemas de drenagem nos limites do Arco de Ponta Grossa. Finalmente, identificamos três espécies supostamente não descritas que mostram um grande déficit de conhecimento da biodiversidade para a região estudada. Palavras-chave: Alto rio Paraná, Escarpa Devoniana, gradiente altitudinal, intercâmbio faunístico. 


\section{Introduction}

Freshwater environments provide numerous ecosystem goods and services that will be lost due to the rapid degradation of aquatic bodies by human activity (Azevedo-Santos et al. 2019a). Local biodiversity inventories are essential in environmental management projects, and provide support for studies involving ecological or biogeographic aspects (Oliveira et al. 2014; Frota et al. 2019). Given that many species in the Neotropical region remain undescribed (Ota et al. 2015) or poorly known, species inventories are essential for widening the known geographic range of the species, and also favor the discovery of new species (Carvalho 2009; Whittaker et al. 2005). In this way, the conservationist practice can only be realized knowing the biodiversity that is intended to be conserved, and inventories are crucial for this finality (Carvalho 2009).

The Neotropical region, the most ichthyologically rich biogeographical domain in the world, comprises about 9,000 fish species (Birindelli \& Sidlauskas 2018). Of these, many are small and inhabit mostly low-order watercourses (Castro 1999; Winemiller et al. 2008), which are estimated to harbor about $50 \%$ of the freshwater fish richness in the tropics (Lowe-McConnell 1999; Winemiller et al. 2008). Even the highly impacted upper rio Paraná system has an estimated 310 species (236 natives), a number outdated by twelve years (Langeani et al. 2007).

Most of the sampling effort that yielded specimens from the rio Paraná basin is due to projects sponsored by the electrical sector, as a consequence of the intense damming to which the basin is subject (Baumgartner et al. 2012). However, these projects focused mostly on larger rivers and, until recently, low-order streams (especially in the Paraná State) still lacked samplings. This scenario changed in recent years as researchers started to focus ecological and biogeographical aspects of several sub-basins of the alto rio Paraná system, increasing our knowledge about the fish species resident in its streams (e.g., Castro et al. 2003; Cetra et al. 2012; Cionek et al. 2012; Pagotto et al. 2012; Costa et al. 2013; Hoffmann et al. 2015; Cetra et al. 2016; Frota et al. 2016a,b; Larentis et al. 2016; Cavalli et al. 2018; Delariva et al. 2018; Claro-García et al. 2018; Frota et al. 2019).

The rio Paranapanema covers about $900 \mathrm{~km}$ (most of which defining the border between Paraná and São Paulo states) from its headwaters in the Serra de Paranapiacaba (São Paulo State) to its mouth in the rio Paraná, being one of its major left-bank tributaries (Ziesler \& Ardizzone 1979). Ichthyofaunistic inventories are available for some of the main sub-basins of the rio Paranapanema system within the Paraná State (Shibatta et al. 2002; Castro et al. 2003; Cetra et al. 2012; Cionek et al. 2012; Pagotto et al. 2012; Costa et al. 2013; Hoffmann et al. 2015; Cetra et al. 2016; Claro-García et al. 2018), but the fishes from the rio das Cinzas and rio Itararé basins remain unknown to the scientific literature, except for one tributary of the former (Costa et al. 2013) and a few streams draining into the latter (Cetra et al. 2016). Thus, this study aimed to provide a new, more inclusive fish inventory for headwater streams of the rio das Cinzas and rio Itararé basins in the Paraná State.

\section{Material and Methods}

\section{Study area}

The rio das Cinzas basin is the main watercourse of the Norte Pioneiro mesoregion of the Paraná State. Its headwaters are located in the Serra de Furnas, in the municipality of Piraí do Sul, west of the
Devonian Escarpment. With a $9,613 \mathrm{~km}^{2}$ watershed encompassing about $5 \%$ of the area and 3\% of the population of Paraná State (Paraná 2010) and a $240 \mathrm{~km}$ course, it forms the border between the municipalities of Santa Mariana and Itambaracá and is one of the main tributaries of the Capivara dam, situated in the rio Paranapanema main channel. The ribeirão Grande, ribeirão Jaboticabal, ribeirão Vermelho, and the rio Laranjinha are the main tributaries of the rio das Cinzas.

The rio Itararé basin is located in the Paraná and São Paulo states. It is born on the border between the municipalities of Bom Sucesso de Itararé (São Paulo State), and Sengés (Paraná State), and runs through much of Northeast of Paraná State until it empties into the rio Paranapanema between the municipalities of Ribeirão Claro (Paraná State) and Timburi (São Paulo State). This watershed has a total area of approximately $4,845 \mathrm{~km}^{2}$, encompassing about $3 \%$ of the area and $1 \%$ of the population of the Paraná State. Its main tributaries situated in the Paraná State are the rio Jaguariaíva and rio Jaguaricatu, which flow into its left bank (Paraná 2010).

Within the rio das Cinzas and rio Itararé basins some protected areas are guaranteed by the National System of Conservation Units of Nature in Brazil, despite of imminent political attacks that are underway (see Alves et al. 2019). Between the municipalities of Cornélio Procópio and Santa Mariana is the Mata São Francisco State Park with 833 ha of Seasonal Forest, in addition to the Mina Velha State Park, in the municipality of Ibaiti, which has remnants of Araucaria forest (Paraná 2010). The Southern portion of the basin, in the municipalities of Piraí do Sul and Jaguariaíva, composes the Environment Protection Area (EPA) of Devonian Escarpment, whose Northern portion includes the rio Itararé, between the municipalities of Jaguariaíva and Sengés. This EPA is a crucial area for biodiversity preservation because it comprises within its limits important State and National Parks, Private Reserve of Natural Heritage, and integrates important Brazilian river basins such as the rio Paranapanema system (Alves et al. 2019).

\section{Data collection}

In all, 24 streams of low orders (less than three) were sampled (Table 1; Figure 1) on two collection trips: June 2017, and July 2018. Of these, seven streams are located in the rio das Cinzas basin, and 17 in the rio Itararé basin (Table 1; Figure 1). A 100-m stretch (the wadeable stream stretches have at least one sequence of riffle-run-pool meso-habitats) was defined at each site, which were georeferenced (Table 1) and sampled by electrofishing. This technique employs two electrified dip nets, producing an electric discharge between 200 and $400 \mathrm{~V}$ and current of $2 \mathrm{~A}$, that stun the fish temporarily (Lobón-Cervia 1991). The specimens were anesthetized in benzocaine hydrochloride and fixed in $10 \%$ formalin in the field. After a few days, the fishes were transferred to $70 \%$ ethanol in the laboratory, identified in species-level, and deposited in the Coleção Ictiológica do Núcleo de Pesquisas em Limnologia, Ictiologia e Aquicultura (NUP).

Fish species were classified based on Van der Laan et al. (2019), species validity was based on Fricke et al. (2019), and species determinations were accomplished by comparison of the specimens with original descriptions or with specimens reported from the streams of rio Paranapanema system in Paraná State (Castro et al. 2003; Cetra et al. 2012; Cionek et al. 2012; Pagotto et al. 2012; Costa et al. 2013; Hoffmann et al. 2015; Cetra et al. 2016; Claro-García et al. 2018) and 
Fishes from rio das Cinzas and rio Itararé basins

Table 1. Information on the headwater streams sampled in the rio das Cinzas and rio Itararé basins, Paraná State, Brazil. Numbers in parentheses after each species name indicates abundance.

\begin{tabular}{|c|c|c|c|c|c|}
\hline $\begin{array}{l}\text { Sampled } \\
\text { site }\end{array}$ & Remarks & $\begin{array}{l}\text { Altitude } \\
\text { (meters) }\end{array}$ & Coordinates & Municipality & Species caught \\
\hline 1 & $\begin{array}{l}\text { Rio do Tigre, affluent of rio } \\
\text { das Cinzas, rio das Cinzas } \\
\text { basin }\end{array}$ & $\sim 783$ & $\begin{array}{l}24^{\circ} 10^{\prime} 24.1^{\prime \prime S} \\
49^{\circ} 53^{\prime} 54.6^{\prime \prime} \mathrm{W}\end{array}$ & Arapoti & Phalloceros harpagos (3) and Rhamdia quelen (2) \\
\hline 2 & $\begin{array}{l}\text { Unnamed river, affluent of } \\
\text { rio Perdizes, rio das Cinzas } \\
\text { basin }\end{array}$ & $\sim 926$ & $\begin{array}{l}24^{\circ} 13^{\prime} 47.2^{\prime \prime} \mathrm{S} \\
49^{\circ} 53^{\prime} 53.6^{\prime \prime} \mathrm{W}\end{array}$ & Arapoti & $\begin{array}{l}\text { Astyanax aff. paranae (145), Geophagus aff. } \\
\text { brasiliensis (3) and Gymnotus inaequilabiatus (2) }\end{array}$ \\
\hline 4 & $\begin{array}{l}\text { Córrego Água Fria, affluent } \\
\text { of rio Pinhalão, rio das } \\
\text { Cinzas basin }\end{array}$ & $\sim 600$ & $\begin{array}{l}23^{\circ} 48^{\prime} 44.1^{\prime \prime S} \\
50^{\circ} 7^{\prime} 55.14^{\prime \prime} \mathrm{W}\end{array}$ & Japira & $\begin{array}{c}\text { Bryconamericus aff. iheringii (7), Cambeva diabola } \\
\text { (5), Hypostomus ancistroides (7), Imparfinis mirini } \\
\text { (19), Phalloceros harpagos (104) and Rhamdia } \\
\text { quelen (3) }\end{array}$ \\
\hline 6 & $\begin{array}{l}\text { Unnamed river, affluent } \\
\text { of rio das Pedras, rio das } \\
\text { Cinzas basin }\end{array}$ & $\sim 626$ & $\begin{array}{l}23^{\circ} 57^{\prime} 28.05^{\prime \prime S} \\
50^{\circ} 14^{\prime} 5.9^{\prime \prime} \mathrm{W}\end{array}$ & Ibaiti & $\begin{array}{c}\text { Astyanax aff. paranae (3), Cambeva diabola (13), } \\
\text { Geophagus aff. brasiliensis (11), Hypostomus } \\
\text { ancistroides (6), Imparfinis mirini (1) and } \\
\text { Neoplecostomus selenae (3) }\end{array}$ \\
\hline 7 & $\begin{array}{l}\text { Rio das Pedras, affluent } \\
\text { of rio das Cinzas, rio das } \\
\text { Cinzas basin }\end{array}$ & $\sim 624$ & $\begin{array}{l}23^{\circ} 56^{\prime} 4.6^{\prime \prime} \mathrm{S} \\
50^{\circ} 14^{\prime} 41.4^{\prime \prime} \mathrm{W}\end{array}$ & Ibaiti & $\begin{array}{c}\text { Astyanax bockmanni (51), Astyanax aff. paranae (8), } \\
\text { Bryconamericus aff. iheringii (78), Cambeva davisi } \\
\text { (6), Geophagus aff. brasiliensis (42), Gymnotus } \\
\text { inaequilabiatus (1), Hoplias aff. malabaricus (3), } \\
\text { Hypostomus ancistroides (19), Neoplecostomus } \\
\text { selenae (17), Phalloceros harpagos (11) and } \\
\text { Rhamdia quelen (2) }\end{array}$ \\
\hline 10 & $\begin{array}{l}\text { Unnamed river, affluent of } \\
\text { rio do Bugre, rio Itararé } \\
\text { basin }\end{array}$ & $\sim 770$ & $\begin{array}{l}24^{\circ} 7 ' 5.1^{\prime \prime S} \\
49^{\circ} 32^{\prime} 50.5^{\prime \prime} \mathrm{W}\end{array}$ & Sengés & $\begin{array}{c}\text { Astyanax aff. paranae (51) and Cambeva iheringi } \\
\text { (13) }\end{array}$ \\
\hline 11 & $\begin{array}{l}\text { Unnamed river, rio Itararé } \\
\text { basin }\end{array}$ & $\sim 949$ & $\begin{array}{l}24^{\circ} 27^{\prime} 43.8^{\prime \prime S} \\
49^{\circ} 31^{\prime} 27.8^{\prime \prime} \mathrm{W}\end{array}$ & Jaguariaíva & $\begin{array}{c}\text { Astyanax aff. paranae (7), Cambeva davisi (4), } \\
\text { Characidium schubarti (3), Neoplecostomus selenae } \\
\text { (8), Phalloceros harpagos (3) and Rhamdia quelen }\end{array}$ \\
\hline 12 & $\begin{array}{l}\text { Rio Preto, affluent of rio } \\
\text { Jaguariaíva, rio Itararé basin }\end{array}$ & $\sim 567$ & $\begin{array}{l}24^{\circ} 4 ' 25.8^{\prime \prime} \mathrm{S} \\
49^{\circ} 38^{\prime} 53.8^{\prime \prime} \mathrm{W}\end{array}$ & Jaguariaíva & $\begin{array}{c}\text { Apareiodon ibitiensis (15), Bryconamericus turiuba } \\
\text { (4), Bryconamericus aff. iheringii (9), Cambeva } \\
\text { davisi (2), Characidium aff. zebra (1), Imparfinis } \\
\text { mirini (2), Neoplecostomus selenae (16) and } \\
\text { Rhamdia quelen (2) }\end{array}$ \\
\hline 13 & $\begin{array}{l}\text { Rio da Serrinha, affluent of } \\
\text { rio Jaguariaíva, rio Itararé } \\
\text { basin }\end{array}$ & $\sim 789$ & $\begin{array}{l}24^{\circ} 12^{\prime} 49.5^{\prime \prime S} \\
49^{\circ} 41^{\prime} 9.1^{\prime \prime} \mathrm{W}\end{array}$ & Jaguariaíva & $\begin{array}{l}\text { Apareiodon ibitiensis (5), Cambeva davisi (1), } \\
\text { Geophagus aff. brasiliensis (2), Neoplecostomus } \\
\text { selenae (11) and Phalloceros harpagos (20) }\end{array}$ \\
\hline 14 & $\begin{array}{l}\text { Rio das Samambaias, } \\
\text { affluent of rio Jaguariaíva, } \\
\text { rio Itararé basin }\end{array}$ & $\sim 813$ & $\begin{array}{l}24^{\circ} 10^{\prime} 43.7^{\prime \prime} \mathrm{S} \\
49^{\circ} 36^{\prime} 55.85^{\prime \prime} \mathrm{W}\end{array}$ & Jaguariaíva & $\begin{array}{c}\text { Cambeva davisi (18), Characidium schubarti } \\
\text { (1), Neoplecostomus selenae (8) and Phalloceros } \\
\text { harpagos (11) }\end{array}$ \\
\hline
\end{tabular}


Frota, A. et al.

Continuation Table 1.

\begin{tabular}{|c|c|c|c|c|c|}
\hline $\begin{array}{l}\text { Sampled } \\
\text { site }\end{array}$ & Remarks & $\begin{array}{l}\text { Altitude } \\
\text { (meters) }\end{array}$ & Coordinates & Municipality & Species caught \\
\hline 15 & $\begin{array}{l}\text { Rio Funil, affluent of rio } \\
\text { Itararé, rio Itararé basin }\end{array}$ & $\sim 620$ & $\begin{array}{l}24^{\circ} 7^{\prime} 15.9^{\prime \prime} \mathrm{S} \\
49^{\circ} 23^{\prime} 28.8^{\prime \prime} \mathrm{W}\end{array}$ & Sengés & $\begin{array}{l}\text { Astyanax bockmanni (4), Geophagus aff. } \\
\text { brasiliensis (5), Hoplias aff. malabaricus (3) and } \\
\text { Neoplecostomus selenae (50) }\end{array}$ \\
\hline 16 & $\begin{array}{l}\text { Rio Pelame, affluent of rio } \\
\text { Itararé, rio Itararé basin }\end{array}$ & $\sim 609$ & $\begin{array}{l}24^{\circ} 7^{\prime} 6.9^{\prime \prime} \mathrm{S} \\
49^{\circ} 24^{\prime} 40.4^{\prime \prime} \mathrm{W}\end{array}$ & Sengés & $\begin{array}{l}\text { Apareiodon ibitiensis (33), Astyanax bockmanni (2), } \\
\text { Astyanax aff. paranae (1), Bryconamericus turiuba } \\
\text { (20), Cambeva diabola (10), Cambeva iheringi (2), } \\
\text { Cetopsorhamdia iheringi (2), Characidium sp. (3), } \\
\text { Eigenmannia sp. (3), Geophagus aff. brasiliensis } \\
\text { (5), Hypostomus hermanni (3), Hypostomus tietensis } \\
\text { (5), Imparfinis borodini (5), Neoplecostomus selenae } \\
\text { (15), Otothyropsis biamnicus (8), Phenacorhamdia } \\
\text { tenebrosa (5) and Piabarchus stramineus (2) }\end{array}$ \\
\hline 17 & $\begin{array}{l}\text { Rio Jaguaricatu, affluent of } \\
\text { rio Itararé, rio Itararé basin }\end{array}$ & $\sim 630$ & $\begin{array}{l}24^{\circ} 8^{\prime} 17.5^{\prime \prime} \mathrm{S} \\
49^{\circ} 29^{\prime} 48.1^{\prime \prime} \mathrm{W}\end{array}$ & Sengés & $\begin{array}{c}\text { Astyanax aff. paranae (5), Cambeva davisi (20), } \\
\text { Geophagus aff. brasiliensis (1) and Neoplecostomus } \\
\text { selenae (52) }\end{array}$ \\
\hline 19 & $\begin{array}{l}\text { Rio Lajeado Grande, } \\
\text { affluent of rio Jaguariaíva, } \\
\text { rio Itararé basin }\end{array}$ & $\sim 1092$ & $\begin{array}{l}24^{\circ} 20^{\prime} 25.8^{\prime \prime} \mathrm{S} \\
49^{\circ} 43^{\prime} 37.9^{\prime \prime} \mathrm{W}\end{array}$ & Jaguariaíva & $\begin{array}{c}\text { Astyanax aff. paranae (1), Characidium schubarti (1) } \\
\text { and Phalloceros harpagos }(124)\end{array}$ \\
\hline 20 & $\begin{array}{l}\text { Unnamed river, affluent of } \\
\text { rio Espigão Alto, rio Itararé } \\
\text { basin }\end{array}$ & $\sim 910$ & $\begin{array}{l}24^{\circ} 25^{\prime} 34.3^{\prime \prime} \mathrm{S} \\
49^{\circ} 40^{\prime} 42.4^{\prime \prime} \mathrm{W}\end{array}$ & Jaguariaíva & $\begin{array}{c}\text { Astyanax aff. paranae (32), Cambeva davisi (18), } \\
\text { Cambeva iheringi (3), Characidium schubarti (10), } \\
\text { Characidium sp. (4), Phalloceros harpagos (8) and } \\
\text { Rhamdia quelen (1) }\end{array}$ \\
\hline 23 & $\begin{array}{l}\text { Unnamed river, affluent of } \\
\text { rio Jaguaricatu, rio Itararé } \\
\text { basin }\end{array}$ & $\sim 942$ & $\begin{array}{l}24^{\circ} 28^{\prime} 18.8^{\prime \prime} \mathrm{S} \\
49^{\circ} 29^{\prime} 28.4^{\prime \prime} \mathrm{W}\end{array}$ & Jaguariaíva & $\begin{array}{c}\text { Astyanax aff. paranae (55), Bryconamericus aff. } \\
\text { iheringii (1), Cambeva davisi (6), Cetopsorhamdia } \\
\text { iheringi (1), Characidium schubarti (3), } \\
\text { Characidium sp. (6), Neoplecostomus selenae (3) } \\
\text { and Phalloceros harpagos (19) }\end{array}$ \\
\hline 24 & $\begin{array}{l}\text { Riacho do Tombo, affluent } \\
\text { of rio Jaguaricatu, rio Itararé } \\
\text { basin }\end{array}$ & $\sim 956$ & $\begin{array}{l}24^{\circ} 29^{\prime} 33.9^{\prime \prime} \mathrm{S} \\
49^{\circ} 29^{\prime} 53.5^{\prime \prime} \mathrm{W}\end{array}$ & Jaguariaíva & $\begin{array}{c}\text { Astyanax aff. paranae (15), Cambeva davisi (10), } \\
\text { Cetopsorhamdia iheringi (6), Characidium sp. } \\
(6), \text { Neoplecostomus selenae (4) and Phalloceros } \\
\text { harpagos (11) }\end{array}$ \\
\hline
\end{tabular}

from the rio Paraná floodplain (Ota et al. 2018). Whenever possible, the determinations of the species were checked by specialists of each taxonomic group. The species were categorized by their frequency of occurrence (hereafter, constancy), which was calculated for all sampled streams according to Dajoz (1983). Species with a constancy up to $25 \%$ were classified as occasional, between 25 and 50\% as accessory, and higher than $50 \%$ as constant. In addition, the species were categorized by origin to distinguish native and introduced species to the upper rio Paraná system, following Langeani et al. (2007), Frota et al. (2016a), Cavalli et al. (2018) and Ota et al. (2018). 


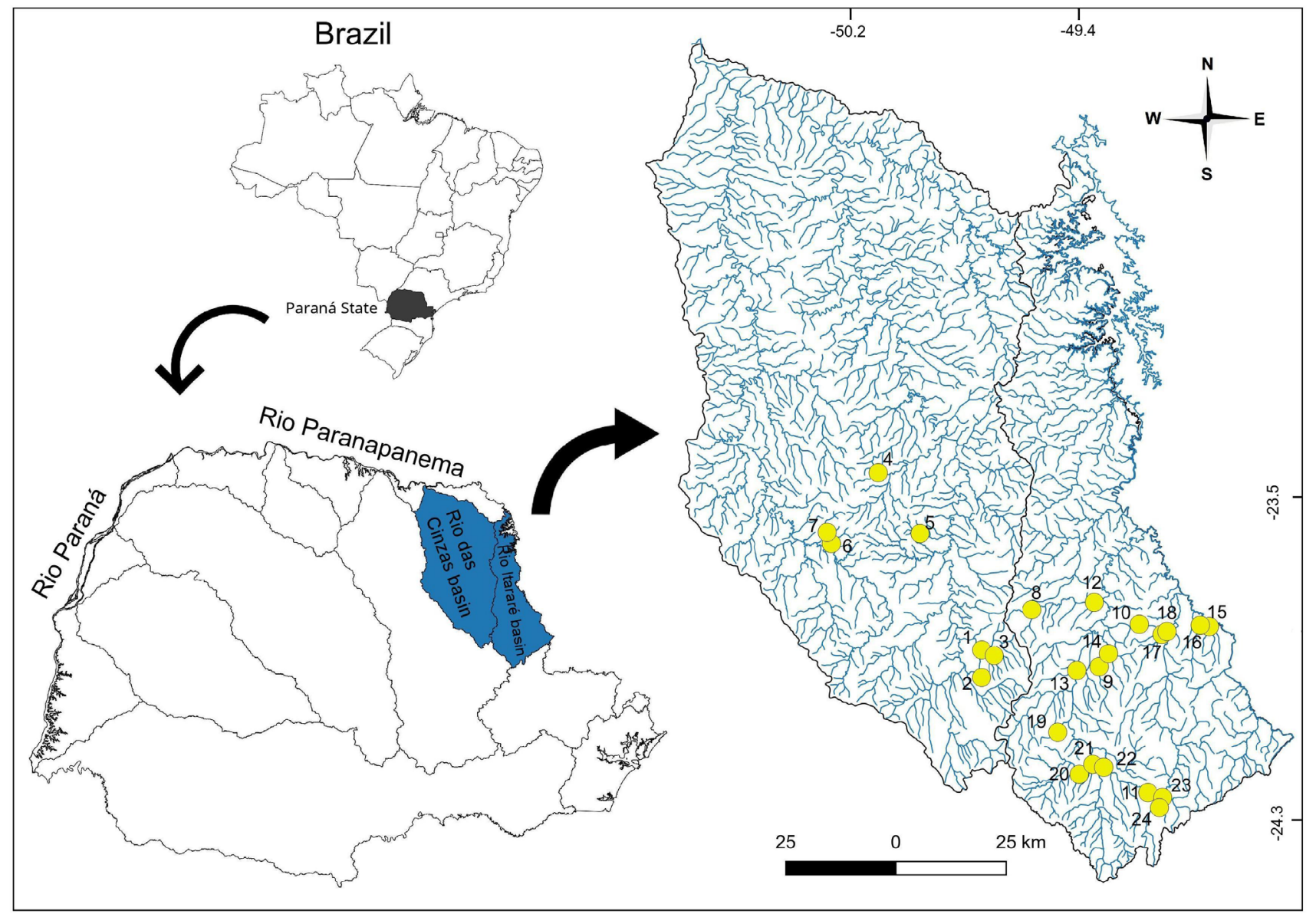

Figure 1. Map of the study area showing the location of the rio das Cinzas and rio Itararé basins within Paraná State and the 24 sampled sites (yellow circles), with its numbers corresponding to Table 1.

\section{Results}

A total of 1,823 individuals were collected, distributed in five orders, 12 families, and 32 species (Tables 1 and 2; Figures 2 and 3). Siluriformes (Figure 2) was the most representative order with 16 species ( $50.0 \%$ of all collected species) and four families, followed by Characiformes (Figure 3) with 12 species and four families. Among the families, Characidae and Loricariidae (both with seven species) presented higher richness contributing together with approximately $43.8 \%$ of all collected species, followed by Heptapteridae (five species) with approximately $15.6 \%$ of all collected species, Crenuchidae and Trichomycteridae (three species each) with approximately $8.8 \%$ of all collected species, and the other families (Table 2) that were represented by only one species.

Regarding the abundance of the sampled individuals (Figure 4), Astyanax aff. paranae Eigenmann, 1914 (447 individuals), Phalloceros harpagos Lucinda, 2008 (321 individuals), Neoplecostomus selenae Zawadzki, Pavanelli \& Langeani, 2008 (208 individuals), Geophagus aff. brasiliensis (Quoy \& Gaimard, 1824) (115 individuals), Cambeva davisi (Haseman, 1911) (112 individuals), Bryconamericus aff. iheringii (Boulenger, 1887) (106 individuals), Characidium schubarti Travassos, 1955 (67 individuals), Astyanax bockmanni Vari \& Castro, 2007 (63 individuals), Apareiodon ibitiensis Amaral Campos, 1944
(59 individuals), and Rhamdia quelen (Quoy \& Gaimard, 1824) (54 individuals) were the most abundant species, contributing with approximately $85.0 \%$ of all collected individuals. On the other hand, the other 22 species counted less than 50 individuals, representing approximately $15.0 \%$ of all collected individuals (Figure 4 ).

As for constancy (Table 2) most of the species were categorized as occasional (25 species). Five species (C. schubarti, R. quelen, C. davisi, $G$. aff. brasiliensis, and $P$. harpagos) were categorized as accessory, and only two species ( $A$. aff. paranae and $N$. selenae) were categorized as constant. Regarding the origin of species (Table 2) none was considered as introduced to the rio Paranapanema system. It is noteworthy that the capture of Astyanax bifasciatus Garavello \& Sampaio, 2010 represents the first record of this species from the upper rio Paraná system. Lastly, three putatively undescribed species (approximately $9.4 \%$ of all collected species) were also collected: A. aff. paranae (sensu Ota et al. 2018), Characidium sp., and Eigenmannia sp.

\section{Discussion}

With the predominance of Siluriformes and Characiformes, the taxonomic composition of the 24 sampled streams follows the pattern described for the Neotropical freshwater fish fauna (Castro 1999; Lowe-McConnell 1999; Albert et al. 2011). The number of species 


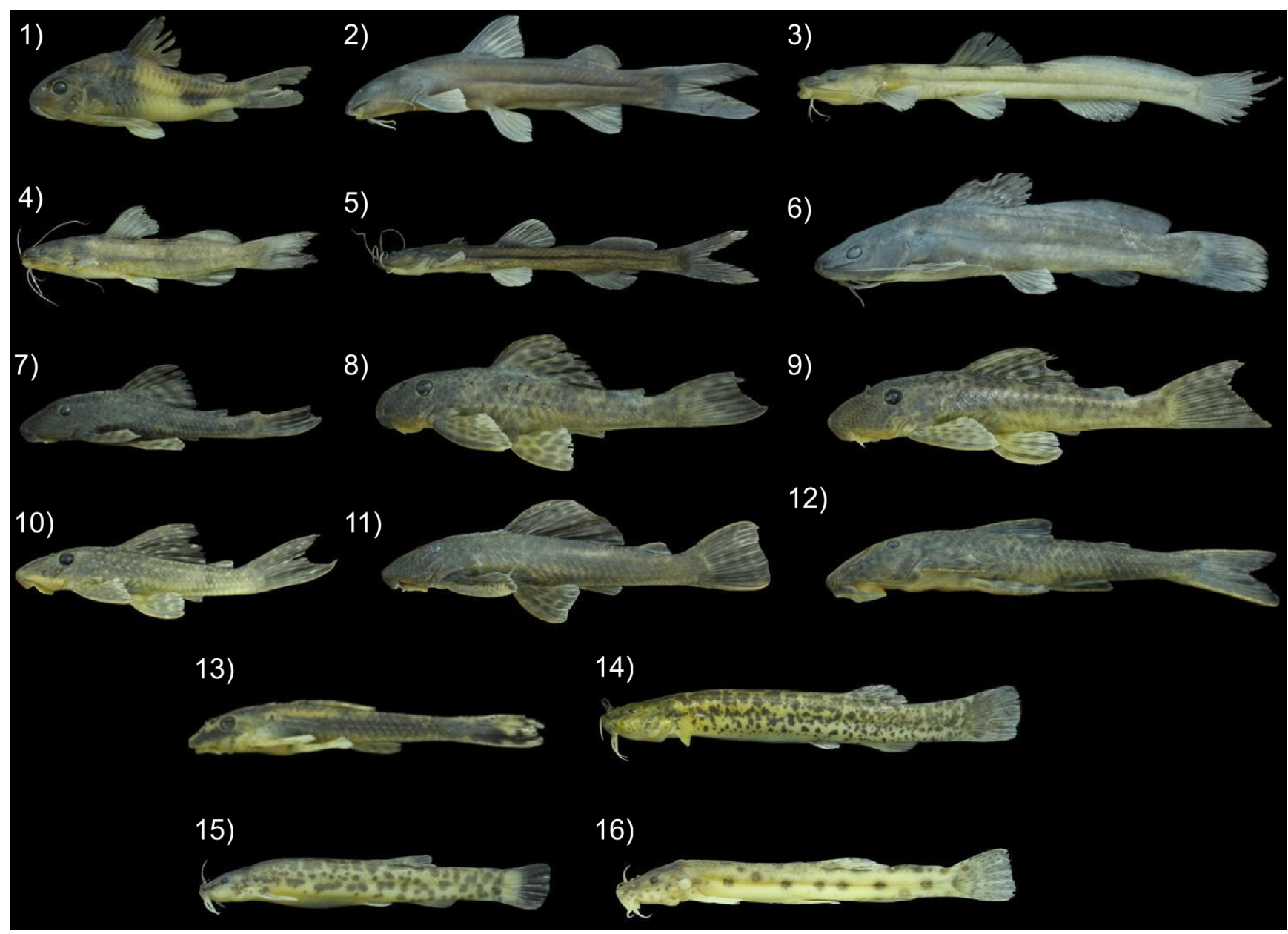

Figure 2. Representative individuals of the Siluriformes collected to the headwater streams from the rio das Cinzas and rio Itararé basins, rio Paranapanema system, Paraná State, Brazil. Their catalogue numbers in the Coleção Ictiológica do Nupélia (NUP) and standard lengths are presented after the names of species. 1) Corydoras ehrhardti, NUP 20473, $43.9 \mathrm{~mm}$; 2) Cetopsorhamdia iheringi, NUP 20490, $70.9 \mathrm{~mm}$; 3) Imparfinis borodini, NUP 20434, $105.2 \mathrm{~mm}$; 4) Imparfinis mirini, NUP 20393, $68.0 \mathrm{~mm}$; 5) Phenacorhamdia tenebrosa, NUP 20437, $59.9 \mathrm{~mm}$; 6) Rhamdia quelen, NUP 20479, $94.8 \mathrm{~mm}$; 7) Hypostomus ancistroides, NUP 20516, $63.8 \mathrm{~mm}$; 8) Hypostomus hermanni, NUP 20432, $99.5 \mathrm{~mm}$; 9) Hypostomus iheringii, NUP 20449, 98.6 mm; 10) Hypostomus strigaticeps, NUP 20450, $106.8 \mathrm{~mm}$; 11) Hypostomus tietensis, NUP 20476, $125.4 \mathrm{~mm}$; 12) Neoplecostomus selenae, NUP 20477, 67.3 mm; 13) Otothyropsis biamnicus, NUP 20436, $27.5 \mathrm{~mm}$; 14) Cambeva davisi, NUP 20462, $74.5 \mathrm{~mm}$; 15) Cambeva diabola, NUP 20510, $55.7 \mathrm{~mm}$; 16) Cambeva iheringi, NUP 20470, $71.7 \mathrm{~mm}$.

recorded in Characidae, Loricariidae, and Heptapteridae also follows the pattern of the most species-rich families in the upper rio Paraná system (Langeani et al. 2007). Similarly, several studies have indicated the prevalence of these families in other streams of this drainage system (e.g., Hoffmann et al. 2015; Bifi et al. 2017; Batista-Silva et al. 2018; Claro-García et al. 2018; Azevedo-Santos et al. 2019b), especially for streams of the rio Paranapanema system, such as the rio das Cinzas (Costa et al. 2013) and the rio Itararé (Cetra et al. 2016) basins.

Our results showed that occasional species dominated the sampled streams. This may be related to the influence of the altitudinal gradient on the species distribution since the species richness tends to decrease with the altitude increase (Fu et al. 2004; Jaramillo-Villa et al. 2010; Askeyev et al. 2017; Frota et al. 2019). As verified in other studies relating fish species richness with the altitudinal gradient (e.g., Askeyev et al. 2017), above $650 \mathrm{~m}$ of altitude few species were repeated in the streams sampled (Table 1). These species were classified as constant or accessory, in addition to being among the most abundant species such as
A. aff. paranae, N. selenae, C. davisi, R. quelen, and C. schubarti. In fact, members of Heptapteridae, Loricariidae, and Trichomycteridae have morphological structures adapted to fixation in underwater structures, such as fortified pectoral fin rays, subterminal sucker mouths and/or spines in the operculum. These adaptations can guarantee the conquest of higher lands, such as headwater streams (Oyakawa et al. 2006). The great abundance and constancy of $A$. aff. paranae may be related to a short-distance migratory character $(<100 \mathrm{~km})$ already evidenced for some species of this genus (Agostinho et al. 2004).

Costa et al. (2013) found a few introduced species already inhabiting the waters of the rio das Cinzas basin, such as Cyprinus carpio Linnaeus, 1768, Oreochromis niloticus (Linnaeus, 1758), and Poecilia reticulata Peters, 1859. In contrast, the absence of such species from the headwater streams sampled herein suggests a greater integrity of that fish community, since biological invasions are among the main threats to freshwater environments (Daga et al. 2015; Ruaro et al. 2018), and especially detrimental for the fish fauna of Neotropical 


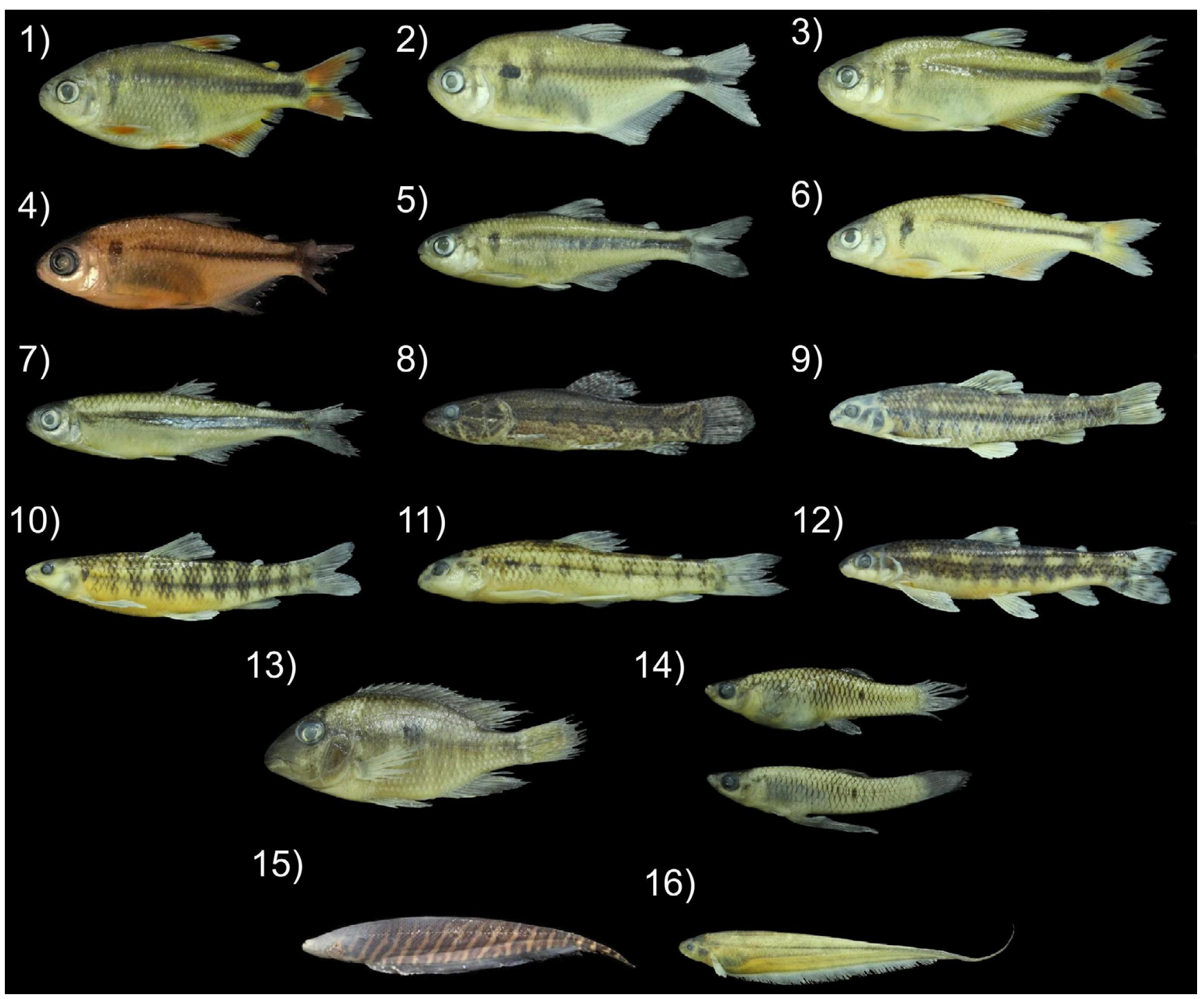

Figure 3. Representative individuals of the Characiformes, Cichliformes, Cyprinodontiformes, and Gymnotiformes collected to the headwater streams from the rio das Cinzas and rio Itararé basins, rio Paranapanema system, Paraná State, Brazil. Their catalogue numbers in the Coleção Ictiológica do Nupélia (NUP) and standard lengths (total lengths for Gymnotiformes) are presented after the names of species. 1) Astyanax bockmanni, NUP 20511, 66.3 mm;2) Astyanax lacustris, NUP 20446, $58.2 \mathrm{~mm}$; 3) Astyanax aff. paranae, NUP 20464, $59.8 \mathrm{~mm}$; 4) Astyanax cf. bifasciatus, NUP 20405, $38.0 \mathrm{~mm}$; 5) Bryconamericus turiuba, NUP 20426, $45.0 \mathrm{~mm}$; 6) Bryconamericus aff. iheringii, NUP 20513, $45.0 \mathrm{~mm}$; 7) Piabarchus stramineus, NUP 20438, 67.5 mm; 8) Hoplias aff. malabaricus, NUP 20475, $77.1 \mathrm{~mm}$; 9) Characidium schubarti, NUP 20472, 68.4 mm; 10) Characidium aff. zebra, NUP 20409, $70.8 \mathrm{~mm}$; 11) Characidium sp., NUP 20491, $48.3 \mathrm{~mm}$; 12) Apareiodon ibitiensis, NUP 20414, $89.6 \mathrm{~mm}$; 13) Geophagus aff. brasiliensis, NUP 20421, $77.5 \mathrm{~mm}$; 14) Phalloceros harpagos, NUP 20487, $29.6 \mathrm{~mm}$ (above; female), $22.9 \mathrm{~mm}$ (below; male); 15) Gymnotus inaequilabiatus, NUP 21109, 108.5 mm; 16) Eigenmannia sp., NUP 20429, 149.0 mm.

streams (Winemiller et al. 2008; Ruaro et al. 2018). The Devonian Escarpment EPA is directly linked to the maintenance of this integrity, especially in the case of the rio Itararé basin, and conservation efforts are increasingly necessary to at least maintain the original area of this natural reserve (Alves et al. 2019).

Astyanax bifasciatus was thought to be endemic to the rio Iguaçu basin (Garavello \& Sampaio 2010; Baumgartner et al. 2012), a drainage system of the lower rio Paraná that encompasses a large area of southern Paraná State and northern Santa Catarina State. In a recent inventory (Frota et al. 2019), this species had its geographical distribution extended to the rio Ribeira de Iguape basin, a coastal drainage bordered to the south by the rio Iguaçu basin and to the north by the rio Itararé basin. Another example of the interesting biogeographic (Ribeiro 2006;
Frota et al. 2016a) and phylogeographic (Morais-Silva et al. 2018) patterns at the boundaries of the Ponta Grossa Arch. In fact, this arch is the most prominent geological structure in the headwater regions of the Paranapanema, Iguaçu and Ribeira de Iguape river basins (Ribeiro 2006).

Mainly due to their recent tectonic activities (Franco-Magalhães et al. 2010), the Ponta Grossa Arch is thought to be responsible for a particularly accelerated river dynamism between these adjacent drainage systems, enabling the faunal exchange between them (Ribeiro 2006). This same scenario can be found for other fish species. For example, adjacent tributaries of the Iguaçu, Paranapanema and Ribeira de Iguape river basins share the presence of $C$. davisi (see Ingenito et al. 2004; Ribeiro 2006; Morais-Silva et al. 2018), Hyphessobrycon griemi 
Frota, A. et al.

Table 2. Fish species collected in headwater streams from the rio das Cinzas and rio Itararé basins, upper rio Paranapanema system, Paraná State, Brazil.

\begin{tabular}{|c|c|c|c|c|}
\hline Ordem & Family & Species & Origin/Constancy & Voucher \\
\hline \multirow[t]{8}{*}{ Characiformes } & \multirow[t]{3}{*}{ Crenuchidae } & $\begin{array}{l}\text { Characidium schubarti } \\
\text { Travassos, } 1955\end{array}$ & Native/Accessory & $\begin{array}{c}\text { NUP 19250, NUP 19265, NUP 20455, NUP } \\
\text { 20459, NUP 20472, NUP 20484, NUP } \\
21055\end{array}$ \\
\hline & & $\begin{array}{l}\text { Characidium aff. zebra } \\
\text { Eigenmann, } 1909\end{array}$ & Native/Occasional & NUP 20409 \\
\hline & & Characidium sp. & Native/Occasional & $\begin{array}{l}\text { NUP 20428, NUP 20458, NUP 20465, NUP } \\
\text { 20485, NUP } 20491\end{array}$ \\
\hline & Parodontidae & $\begin{array}{l}\text { Apareiodon ibitiensis Amaral } \\
\text { Campos, } 1944\end{array}$ & Native/Occasional & $\begin{array}{l}\text { NUP 20407, NUP 20414, NUP 20425, NUP } \\
\text { 20445, NUP 21013, NUP } 21017\end{array}$ \\
\hline & \multirow[t]{4}{*}{ Characidae } & $\begin{array}{c}\text { Astyanax bockmanni Vari \& } \\
\text { Castro, } 2007\end{array}$ & Native/Occasional & $\begin{array}{l}\text { NUP 20423, NUP 20431, NUP 20511, NUP } \\
21111\end{array}$ \\
\hline & & $\begin{array}{c}\text { Astyanax cf. bifasciatus } \\
\text { Garavello \& Sampaio, } 2010\end{array}$ & Native/Occasional & NUP 20405 \\
\hline & & $\begin{array}{l}\text { Bryconamericus turiuba } \\
\text { Langeani, Lucena, Pedrini \& } \\
\text { Tarelho-Pereira, } 2005\end{array}$ & Native/Occasional & $\begin{array}{c}\text { NUP 20426, NUP 20447, NUP 21015, NUP } \\
21041\end{array}$ \\
\hline & & $\begin{array}{l}\text { Bryconamericus aff. iheringii } \\
\text { (Boulenger, 1887) }\end{array}$ & Native/Occasional & $\begin{array}{l}\text { NUP 20392, NUP 20399, NUP 20408, NUP } \\
\text { 20482, NUP 20513, NUP } 21080\end{array}$ \\
\hline \multirow{7}{*}{ Siluriformes } & \multirow{4}{*}{ Heptapteridae } & $\begin{array}{c}\text { Imparfinis borodini Mees \& } \\
\text { Cala, } 1989\end{array}$ & Native/Occasional & NUP 20434, NUP 21033 \\
\hline & & $\begin{array}{l}\text { Imparfinis mirini Haseman, } \\
1911\end{array}$ & Native/Occasional & $\begin{array}{l}\text { NUP 20393, NUP 20410, NUP 20452, NUP } \\
21012\end{array}$ \\
\hline & & $\begin{array}{l}\text { Phenacorhamdia tenebrosa } \\
\text { (Schubart, 1964) }\end{array}$ & Native/Occasional & NUP 20437, NUP 21034 \\
\hline & & $\begin{array}{l}\text { Rhamdia quelen (Quoy \& } \\
\text { Gaimard, 1824) }\end{array}$ & Native/Accessory & $\begin{array}{c}\text { NUP 19253, NUP 19259, NUP 19264, NUP } \\
\text { 20396, NUP 20402, NUP 20406, NUP } \\
\text { 20412, NUP 20461, NUP 20468, NUP } \\
20479\end{array}$ \\
\hline & \multirow[t]{3}{*}{ Trichomycteridae } & $\begin{array}{c}\text { Cambeva davisi (Haseman, } \\
\text { 1911) }\end{array}$ & Native/Accessory & $\begin{array}{c}\text { NUP 19251, NUP 19267, NUP 20403, NUP } \\
\text { 20413, NUP 20420, NUP 20444, NUP } \\
\text { 20462, NUP 20469, NUP 20488, NUP } \\
\text { 20494, NUP } 21003\end{array}$ \\
\hline & & $\begin{array}{l}\text { Cambeva diabola (Bockmann, } \\
\text { Casatti \& de Pinna, 2004) }\end{array}$ & Native/Occasional & $\begin{array}{c}\text { NUP 20397, NUP 20439, NUP 20510, NUP } \\
\text { 20999, NUP } 21043\end{array}$ \\
\hline & & $\begin{array}{c}\text { Cambeva iheringi (Eigenmann, } \\
\text { 1917) }\end{array}$ & Native/Occasional & $\begin{array}{c}\text { NUP 19261, NUP 20440, NUP 20463, NUP } \\
\text { 20470, NUP 20480, NUP 21042, NUP } \\
21059\end{array}$ \\
\hline
\end{tabular}


Continuation Table 2.

\begin{tabular}{|c|c|c|c|c|}
\hline Ordem & Family & Species & Origin/Constancy & Voucher \\
\hline & Callichthyidae & $\begin{array}{l}\text { Corydoras ehrhardti } \\
\text { Steindachner, } 1910\end{array}$ & Native/Occasional & NUP 20466, NUP 20473, NUP 21075 \\
\hline & \multirow[t]{5}{*}{ Loricariidae } & $\begin{array}{l}\text { Hypostomus ancistroides } \\
\text { (Ihering, 1911) }\end{array}$ & Native/Occasional & $\begin{array}{l}\text { NUP 20394, NUP 20400, NUP 20451, NUP } \\
\text { 20509, NUP } 20516\end{array}$ \\
\hline & & $\begin{array}{l}\text { Hypostomus hermanni } \\
\quad \text { (Ihering, 1905) }\end{array}$ & Native/Occasional & NUP 20432, NUP 21032 \\
\hline & & $\begin{array}{l}\text { Hypostomus strigaticeps } \\
\quad \text { (Regan, 1908) }\end{array}$ & Native/Occasional & NUP 20450, NUP 21050 \\
\hline & & $\begin{array}{l}\text { Hypostomus tietensis (Ihering, } \\
1905 \text { ) }\end{array}$ & Native/Occasional & NUP 20433, NUP 20476 \\
\hline & & $\begin{array}{l}\text { Otothyropsis biamnicus } \\
\text { Calegari, Lehmann \& Reis, } \\
2013\end{array}$ & Native/Occasional & NUP 20436, NUP 21040 \\
\hline Cichliformes & Cichlidae & $\begin{array}{l}\text { Geophagus aff. brasiliensis } \\
\text { (Quoy \& Gaimard, 1824) }\end{array}$ & Native/Accessory & 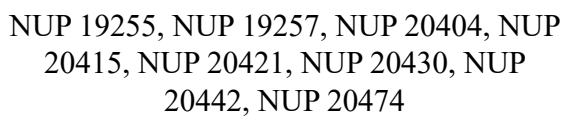 \\
\hline Cyprinodontiformes & Poeciliidae & $\begin{array}{l}\text { Phalloceros harpagos Lucinda, } \\
2008\end{array}$ & Native/Accessory & $\begin{array}{l}\text { NUP 19252, NUP 19263, NUP 20395, NUP } \\
\text { 20417, NUP 20419, NUP 20456, NUP } \\
\text { 20460, NUP 20467, NUP 20478, NUP } \\
\text { 20487, NUP } 20493\end{array}$ \\
\hline
\end{tabular}

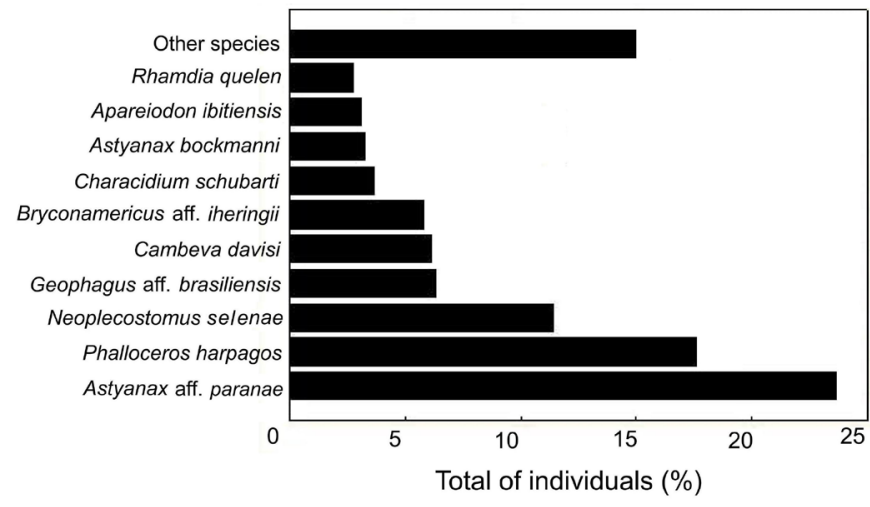

Figure 4. Percentages of number of individuals of each species with more than 50 individuals collected in the headwater streams from rio das Cinzas and rio Itararé basins, rio Paranapanema system, Paraná State, Brazil.

Hoedeman, 1957, H. bifasciatus Ellis, 1911, H. reticulatus Ellis, 1911 (see Ingenito et al. 2004; Ribeiro 2006), Mimagoniates microlepis (Steindachner, 1877) (see Ingenito et al. 2004; Ribeiro 2006; Menezes et al. 2008; Hoffmann et al. 2015), and Rhamdiopsis moreirai Haseman, 1911 (see Ferraris 2007; Hoffmann et al. 2015). The slopes of the upper rio Paraná system and the rio Ribeira de Iguape basin share the presence of Hypostomus ancistroides (Ihering, 1911) (Oyakawa et al. 2005). The Iguaçu and Ribeira de Iguape river basins share the presence of Characidium travassosi Melo, Buckup \& Oyakawa, 2016 (Frota et al. 2016b; Melo et al. 2016). Now, the geographic distribution of A. bifasciatus is added to the mentioned examples since this species also occurs in all drainage systems mentioned.

Nine of the 32 fish species records presented herein are new for the Itararé and Cinzas river basins. Those are Bryconamericus turiuba Langeani, Lucena, Pedrini \& Tarelho-Pereira, 2005, Corydoras ehrhardti Steindachner, 1910, Hypostomus iheringii (Regan, 1908), Hypostomus tietensis (Ihering, 1905), Cambeva iheringi (Eigenmann, 1917), Gymnotus inaequilabiatus Valenciennes, 1839, and the three putatively new species $A$. aff. paranae (sensu Ota et al. 2018), Characidium sp., and Eigenmannia sp. (compare with Costa et al. 2013; Cetra et al. 2016). Except for the latter two species, which are being reported for the first time herein, all of these species have a wide distribution range within the upper rio Paraná drainage. On the other hand, Costa et al. (2013) reported 11 species not collected by us (introduced species excluded): Piabina argentea Reinhardt, 1867, Apareiodon affinis (Steindachner, 1879), Gymnotus sylvius Albert \& Fernandes-Matioli, 1999, Gymnotus sp., Imparfinis schubarti (Gomes, 1956), Hypostomus albopunctatus (Regan, 1908), H. nigromaculatus (Schubart, 1964), H. paulinus (Ihering, 1905), Rineloricaria pentamaculata Langeani \& Araujo, 1994, Crenicichla jaguarensis Haseman, 1911, and Synbranchus marmoratus Bloch, 1795. Cetra et al. (2016) recorded 19 (introduced species excluded): Astyanax biotae Castro \& Vari, 2004, A. scabripinnis (Jenyns, 1842), Hyphessobrycon anisitsi (Eigenmann, 1907), Oligosarcus paranensis Menezes \& 
Géry, 1983, Piabina argentea, Characidium gomesi Travassos, 1956, Parodon nasus Kner, 1859, Gymnotus sylvius, Eigenmannia virescens (Valenciennes, 1836), Pimelodella avanhandavae Eigenmann, 1917, Hypostomus nigromaculatus, Hypostomus sp. 1, Hypostomus sp. 2, Otothyropsis sp., Rineloricaria pentamaculata, Trichomycterus sp. 1, Trichomycterus sp. 2, Phalloceros reisi Lucinda, 2008, and Synbranchus marmoratus.

The identification of $A$. biotae, $H$. anisitsi, $P$. argentea, $O$. paranensis, C. gomesi, A affinis, H. albopunctatus, H. nigromaculatus, $R$. pentamaculata, $P$. avanhandavae, $P$. reisi, $C$. jaguarensis, and $S$. marmoratus is pretty straightforward, meaning that at least 13 species, other than those presented by us, could be added to a complete list of the native stream fish fauna from the upper rio Paranapanema system. However, a careful analysis of the remaining species is necessary in order to verify whether they are in fact distinct from the species listed herein. Gymnotus species are hardly distinguishable from one another, especially at small sizes. Imparfinis schubarti has been considered a junior synonym of I. mirini Haseman, 1911, which suggests that the usual diagnostic characters may not be sufficient to distinguish those species, in the case that they are in fact two species. Hypostomus paulinus represents a species complex and is easily confused with $H$. tietensis (Zawadzki, personal communication).

Some species considered to be new by other authors (Costa et al. 2013; Cetra et al. 2016) may be variants of other, described species, which cannot be verified presently without the examination of the specimens. For example, regarding the two supposedly new species of Trichomycterus (= Cambeva), we found among our specimens a wide color-pattern variation, which nonetheless fall within the range of variation observed by Nascimento et al. (2017) for $C$. davisi and by da Silva et al. (2010) for $C$. iheringi. Thus, we cautiously hypothesize Trichomycterus sp. 1 and Trichomycterus sp. 2 of Cetra et al. (2016) to represent variants of these species.

In any case, in addition to the results of Cetra et al. (2016), our results point to the gap between existing evolutionary knowledge and current biological knowledge, which characterizes a large biodiversity shortfall (Hortal et al. 2015), especially for the stream fish fauna from the rio Paranapanema system. Future taxonomic studies with morphological and molecular methodologies can be conclusive on these issues. Here we have improved knowledge of the fish fauna of the rio das Cinzas and rio Itararé basins, upper rio Paranapanema system. However, we recognize that this inventory likely represents a small fraction of what remains to be sampled within these basins. Once again, sampling at headwater regions of high altitudes revealed possible unknown species to science, interesting biogeographic patterns and alarming biodiversity shortfalls, as well as inherent concerns about anthropogenic actions in Brazilian freshwater environments.

\section{Acknowledgements}

We are deeply grateful to Francisco Alves Teixeira (UEM), Valmir Alves Teixeira (UEM), and Wladimir Marques Domingues (UEM) for the aid in the field trip; to Cláudio Zawadzki (UEM), Carlos Oliveira (UEM), and Fernando Carvalho (UFMS) for help in fish identification; to Marli Campos (Nupélia) by cataloging the vouchers. We thanks to Committee of Ethics for the Use of Animals in Experimentation, State
University of Maringá (UEM) by the approval of samplings (process number 5680160117), and to Brazilian Institute of Environment and Renewable Natural Resources (IBAMA, in Portuguese) by the permanent license to collect zoological material (number 14028-1) conceived to WJG. AF and WJG received grants from Fundação Araucária. AF, MJMG, and RRO has been supported by scholarship from Conselho Nacional de Desenvolvimento Científico e Tecnológico (CNPq). WJG received personal grants from CNPq (305200/2018-6).

\section{Author Contributions}

Augusto Frota: contributed to data acquisition, analysis and interpretation of data, drafting of the manuscript and wrote the paper.

Renata Rúbia Ota: contributed to analysis and interpretation of data, and critical revision for adding substantive intellectual content.

Gabriel de Carvalho Deprá: contributed to analysis and interpretation of data, and critical revision for adding substantive intellectual content.

Maria Julia Mileo Ganassin: contributed to analysis and interpretation of data, and critical revision for adding substantive intellectual content.

Weferson Júnio da Graça: contributed to data acquisition, analysis and interpretation of data, and critical revision for adding substantive intellectual content.

\section{Conflicts of interest}

The authors declare that they have no conflict of interest related to the publication of this manuscript.

\section{References}

AGOSTINHO, A.A., GOMES, L.C., VERÍSSIMO, S. \& OKADA, E.K. 2004. Flood regime, dam regulation and fish in the Upper Paraná River: effects on assemblage attributes, reproduction and recruitment. Rev. Fish Biol. Fisher. 14(1): 11-19.

ALBERT, J., PETRY, P. \& REIS, R.E. 2011. Major biogeographic and phylogenetic patterns. In Historical biogeography of Neotropical freshwater fishes (J.S. Albert \& R.E. Reis, eds). University of California Press, Berkeley, p.21-56.

ALVES, G.H., SANTOS, R.S., FIGUEIREDO, B.R.S., MANETTA, G.I., MESSAGE, H.J., PAZIANOTO, L.H.R., GUIMARÃES, G.B., BENEDITO, E. \& COUTO, E.V. 2019. Misguided policy may jeopardize a diverse South brazilian environmental protection area. Biota Neotrop. 19(1): e20180574. http://dx.doi.org/10.1590/1676-0611-BN-2018-0574 (last access 16 June 2019).

ASKEYEV, A., ASKEYEV, O., YANYBAEV, N., ASKEYEV, I., MONAKHOV, S., MARIĆ, S. \& HULSMAN, K. 2017. River fish assemblages along an elevation gradient in the eastern extremity of Europe. Environ. Biol. Fish. 100(5): 585-596.

AZEVEDO-SANTOS, V.M., FREDERICO, R.G., FAGUNDES, C.K., POMPEU, P.S., PELICICE, F.M., PADIAL, A.A., NOGUEIRA, M.G., FEARNSIDE, P.M., LIMA, L.B., DAGA, V.S., OLIVEIRA, F.J.M., VITULE, J.R., CALliSTO, M., AGOSTINHO, A.A., ESTEVES, F.A., LIMA-JUNIOR, D.P., MAGALHÃES, A.L.B., SABINO, J., MORMUL, R.P., GRASEL, D., ZUANON, J., VILELLA, F.S. \& HENRY, R. 2019a. Protected areas: a focus on Brazilian freshwater biodiversity. Divers. Distrib. 25(3): 442-448 
AZEVEDO-SANTOS, V.M., BRITSKI, H.A., OLIVEIRA, C. \& BENINE, R.C. 2019b. Ichthyofauna of streams of the Rio Sapucaí basin, upper Rio Paraná system, Minas Gerais, Brazil. Biota Neotrop. 19(1): e20180617 http:// dx.doi.org/10.1590/1676-0611-BN-2018-0617 (last access 18 June 2019).

BATISTA-SILVA, V.F., FROTA, A., KASHIWAQUI, E.A.L., ABELHA, M.C.F., BAILLY, D., GUBIANI, E.A. \& GRAÇA, W.J. 2018. Ichthyofauna from three streams of the lower Iguatemi River in the upper Paraná river basin, Brazil. Check List 14(2): 363-378.

BAUMGARTNER, G., PAVANELLI, C.S., BAUMGARTNER, D., BIFI, A.G., DEBONA, T. \& FRANA, V.A. 2012. Peixes do Baixo Rio Iguaçu. Eduem, Maringá.

BIFI, A.G., DIAS, A.C. \& FROTA, A. 2017. Fish species (Osteichthyes: Actinopterygii) from two tributaries of the Rio do Peixe basin, Tupã municipality, São Paulo state, Brazil. Check List 13(2): 2063.

BIRINDELLI, J.L.O. \& SIDLAUSKAS, B.L. 2018. Preface: How far has Neotropical Ichthyology in twenty years? Neotrop. Ichthyol. 16(3): e180128.

CASTRO, R.M.C. 1999. Evolução da ictiofauna de riachos sul americanos: padrões gerais e possíveis processos casuais. In Ecologia de peixes de riachos: estado atual e perspectivas (E.P. Caramaschi, R. Mazzoni \& P.R. Peres-Neto, eds). UFRJ, Rio de Janeiro, p.139-155.

CASTRO, R.M.C., CASATTI, L., SANTOS, H.F., FERREIRA, K.M., RIBEIRO, A.C., BENINE, R.C., DARDIS, G.Z.P., MELO, A.L.A., ABREU, T.X., BOCKMANN, F.A., CARVALHO, M., GIBRAN, F.Z. \& LIMA, F.C.T. 2003. Estrutura e composição da ictiofauna de riachos do Rio Paranapanema, sudeste e sul do Brasil. Biota Neotrop. 3(1): 1-31. http:// www.biotaneotropica.org.br/v3n1/pt/abstract?article+BN01703012003 (last access 13 June 2019).

CARVALHO, C.J.B. 2009. Padrões de endemismos e a conservação da biodiversidade. Megadiversidade(1-2): 77-86.

CAVALLI, D., FROTA, A., LIRA, A.D., GUBIANI, E.A., MARGARIDO, V.P. \& GRAÇA, W.J. 2018. Update on the ichthyofauna of the Piquiri River basin, Paraná, Brazil: a conservation priority area. Biota Neotrop. 18(2): e20170350. http://dx.doi.org/10.1590/1676-0611-BN-2017-0350 (last access 13 June 2019).

CETRA, M., BARRELLA, W., LANGEANI NETO, F., MARTINS, A.G., MELLO, B.J. \& ALMEIDA, R.S. 2012. Fish fauna of headwater streams that cross Atlantic Forest of south São Paulo state. Check List 8(3): 421-425.

CETRA, M., MATTOX, G.M.T., FERREIRA, F.C., GUINATO, R.B., SILVA, F.V. \& PEDROSA, M. 2016. Headwater stream fish fauna from the Upper Paranapanema River basin. Biota Neotrop. 16(3): e20150145. http://dx.doi. org/10.1590/1676-0611-BN-2015-0145 (last access 13 June 2019).

CIONEK, V.M., SACRAMENTO, P.A., ZANATTA, N., OTA, R.P., CORBETTA, D.F. \& BENEDITO, E. 2012. Fishes from first order streams of lower Paranapanema and Ivaí rivers, upper Paraná River basin, Paraná, Brazil. Check List 8(6): 1158-1162.

CLARO-GARCÍA, A., ASSEGA, F.M. \& SHIBATTA, O.A. 2018. Diversity and distribution of ichthyofauna in streams of the middle and lower Tibagi river basin, Paraná, Brazil. Check List 14(1): 43-53.

COSTA, A.D.A., FERREIRA, D.G., SILVA, W.F., ZANATTA, A.S., SHIBATTA, O.A. \& GALINDO, B.A. 2013. Fishes (Osteichthyes: Actinopterygii) from the Penacho stream, upper Paraná River basin, Paraná State, Brazil. Check List 9(3): 519-523.

DAGA, V.S., SKÓRA, F., PADIAL, A.A., ABILHOA, V., GUBIANI, É.A. \& VITULE, J.R.S. 2015. Homogenization dynamics of the fish assemblages in Neotropical reservoirs: comparing the roles of introduced species and their vectors. Hydrobiologia 746(1): 327-347.

DAJOZ, R. 1983. Ecologia geral. Vozes, Petrópolis.

DELARIVA, R.L., NEVES, M.P., LARENTIS, C., KLIEMANN, B.C.K., BALDASSO, M.C. \& WOLFF, L.L. 2018. Fish fauna in forested and rural streams from an ecoregion of high endemism, lower Iguaçu River basin, Brazil. Biota Neotrop. 18(3): e20170459. http://dx.doi.org/10.1590/16760611-bn-2017-0459 (last access 17 June 2019).

FERRARIS, C.J. 2007. Checklist of catfishes, recent and fossil (Osteichthyes: Siluriformes), and catalogue of siluriform primary types. Zootaxa 1418(1): $1-628$.
FRANCO-MAGALHAES, A.O.B., HACKSPACHER, P.C., GLASMACHER, U.A. \& SAAD, A.R. 2010. Rift to post-rift evolution of a "passive" continental margin: the Ponta Grossa Arch, SE Brazil. Int. J. Earth Sci. 99(7): 1599-1613.

FRICKE, R., ESCHMEYER, W.N. \& FONG, J.D. 2019. Eschmeyer's Catalog of Fishes: Genera, Species, References. http://researcharchive.calacademy. org/research/ichthyology/catalog/fishcatmain.asp (last access 13 June 2019).

FROTA, A., DEPRÁ, G.C., PETENUCCI, L.M. \& GRAÇA, W.J. $2016 \mathrm{a}$. Inventory of the fish fauna from Ivaí River basin, Paraná State, Brazil. Biota Neotrop. 16(3): e20150151 http://dx.doi.org/10.1590/1676-0611BN-2015-0151 (last access 13 June 2019).

FROTA, A., GONÇALVES, E.V.R., DEPRÁ, G.C. \& GRAÇA, W.J. 2016 b. Inventory of the ichthyofauna from the Jordão and Areia river basins (Iguaçu drainage, Brazil) reveals greater sharing of species than thought. Check List 12(6): 1995.

FROTA, A., MESSAGE, H.J., OLIVEIRA, R.C., BENEDITO, E. \& GRAÇA, W.J. 2019. Ichthyofauna of headwater streams from the rio Ribeira de Iguape basin, at the boundaries of the Ponta Grossa Arch, Paraná, Brazil. Biota Neotrop. 19(1): e20180666 http://dx.doi.org/10.1590/1676-0611BN-2018-0666 (last access 17 June 2019).

FU, C., WU, J., WANG, X., LEI, G. \& CHEN, J. 2004. Patterns of diversity, altitudinal range and body size among freshwater fishes in the Yangtze River Basin, China. Global Ecol. Biogeogr. 13(6): 43-552.

GARAVELLO, J.C. \& SAMPAIO, F.A.A. 2010. Five new species of genus Astyanax Bird \& Girard, 1854 from Rio Iguaçu, Paraná, Brazil (Ostariophysi, Characiformes, Characidae). Braz. J. Biol. 70(3): 847-865.

HOFFMANN, A.C., NASCIMENTO, R.H.C. \& SHIBATTA, O.A. 2015. Fish fauna from tributaries throughout the Tibagi River basin, upper Paraná basin, Brazil. Check List 11(6): 1815.

HORTAL, J., BELLO, F., DINIZ-FILHO, J.A.F., LEWINSOHN, T.M., LOBO, J.M. \& LADLE, R.J. 2015. Seven shortfalls that beset large-scale knowledge of biodiversity. Annu. Rev. Ecol. Evol. S. 46: 523-549.

INGENITO, L.F.S., DUBOC, L.F. \& ABILHOA, V. 2004. Contribuição ao conhecimento da ictiofauna da bacia do alto rio Iguaçu, Paraná, Brasil. Arquivos de Ciências Veterinárias e Zoológicas da UNIPAR 7(1): 23-36.

JARAMILLO-VILLA, U., MALDONADO-OCAMPO, J.A. \& ESCOBAR, F. 2010. Altitudinal variation in fish assemblage diversity in streams of the central Andes of Colombia. J. Fish Biol. 76(10): 2401-2417.

LANGEANI, F., CASTRO, R.M.C., OYAKAWA, O.T., SHIBATTA, O.A., PAVANELLI, C.S. \& CASATTI, L. 2007. Diversidade da ictiofauna do Alto Rio Paraná: composição atual e perspectivas futuras. Biota Neotrop. 7(3): 181-197 http://www.biotaneotropica.org.br/v7n3/pt/ abstract?article+bn0340703 (last access 13 June 2019).

LARENTIS, C., DELARIVA, R.L., GOMES, L.C., BAUMGARTNER, D., RAMOS, I.P. \& SEREIA, D.A.O. 2016. Ichthyofauna of streams from the lower Iguaçu River basin, Paraná State, Brazil. Biota Neotrop. 16(3): e20150117 http://dx.doi.org/10.1590/1676-0611-BN-2015-0117 (last access 17 June 2019).

LOBÓN-CERVIÁ, J. 1991. Dinámica de poblaciones de peces en rios: pesca eléctrica y métodos de capturas sucesivas en la estima de abundancias. Monografia, Consejo Superior de Investigaciones Científicas, Museo Nacional de Ciencias Naturales, Madrid.

LOWE-MCCONNELL, R.H. 1999. Estudos ecológicos de comunidades de peixes tropicais. EDUSP, São Paulo.

MELO, M.R.S., BUCKUP, P.A. \& OYAKAWA, O.T. 2016. A new species of Characidium Reinhardt, 1867 (Characiformes: Crenuchidae) endemic to the Atlantic Forest in Paraná State, Southern Brazil. Neotrop. Ichthyol. 14(3): e160014.

MENEZES, N.A., RIBEIRO, A.C. WEITZMAN, S. \& TORRES, R.A. 2008. Biogeography of Glandulocaudinae (Teleosei: Characiformes: Characidae) revisited: phylogenetic patterns, historical geology and genetic connectivity. Zootaxa 1726(1): 33-48.

MORAIS-SILVA, J.P., OLIVEIRA, A.V., FABRIN, T.M.C., DIAMANTE, N.A., PRIOLI, S.M.A.P., FROTA, A., GRAÇA, W.J. \& PRIOLI, A.J. 2018. Geomorphology influencing the diversification of fish in small-order rivers of neighboring basins. Zebrafish 15(4): 389-397. 
NASCIMENTO, R.H.C., FRANTINE-SILVA, W., SOUZA-SHIBATTA, L., SOFIA, S.H., FERRER, J. \& SHIBATTA, O.A. 2017. Intrapopulational variation in color pattern of Trichomycterus davisi (Haseman, 1911) (Siluriformes: Trichomycteridae) corroborated by morphometrics and molecular analysis. Zootaxa 4290(3): 503-518.

OLIVEIRA, A.G., GOMES, L.C., LATINI, J.D. \& AGOSTINHO, A.A. 2014. Implications of using a variety of fishing strategies and sampling techniques across different biotopes to determine fish species composition and diversity. Nat. Conservação 12(2): 112-117.

OTA, R.R., MESSAGE, H.J., GRAÇA, W.J. \& PAVANELLI, C.S. 2015. Neotropical Siluriformes as a model for insights on determining biodiversity of animal groups. PLoS ONE 10(7): e0132913.

OTA, R.R., DEPRÁ, G.C., GRAÇA, W.J. \& PAVANELLI, C.S. 2018. Peixes da planície de inundação do alto rio Paraná e áreas adjacentes: revised, annotated and updated. Neotrop. Ichthyol. 16(2): e170094.

OYAKAWA, O.T., AKAMA, A. \& ZANATA, A.M. 2005. Review of the genus Hypostomus Lacépède, 1803 from rio Ribeira de Iguape basin, with description of a new species (Pisces, Siluriformes, Loricariidae). Zootaxa 921(1): 1-27.

OYAKAWA, O.T., AKAMA, A., MAUTARI, K.C. \& NOLASCO, J.C. 2006. Peixes de riachos da Mata Atlântica. Neotrópica, São Paulo.

PAGOTTO, J.P.A., VERÍSSIMO, S., GOULART, E. \& MISE, F.T. 2012. Fishes (Osteichthyes: Actinopterygii) from the Pirapó River drainage, upper Paraná River basin, Paraná state, Brazil. Check List 8(3): 463-468.

PARANÁ. Secretaria do Estado do Meio Ambiente e Recursos Hídricos SEMA. 2010. Bacias hidrográficas do Paraná. SEMA, Curitiba http://www. meioambiente.pr.gov.br/arquivos/File/corh/Revista_Bacias_Hidrograficas do_Parana.pdf (last access 16 June 2019).
RUARO, R., MORMUL, R.P., GUBIANI, É.A., PIANA, P.A., CUNICO, A.M. \& GRACCA, W.J. 2018. Non-native fish species are related to the loss of ecological integrity in Neotropical streams: a multimetric approach. Hydrobiologia 817(1): 413-430.

RIBEIRO, A.C. 2006. Tectonic history and the biogeography of the freshwater fishes from the coastal drainages of eastern Brazil: an example of faunal evolution associated with a divergent continental margin. Neotrop. Ichthyol. 4(2): 225-246.

SHIBATTA, O.A., ORSI, M.L., BENNEMANN, S.T. \& SILVA-SOUZA, A.T. 2002. Diversidade e distribuição de peixes na bacia do rio Tibagi. In: A Bacia do Rio Tibagi (M.E. Medri, E. Bianchini, O.A. Shibatta, J.A. Pimenta, eds.). M.E. Medri, Londrina, p. 403-424.

DA SILVA, C.C.F., MATTA, L.S.F., HILSDORF, A.W.S., LANGEANI, F. \& MARCENIUK, A.P. 2010. Color pattern variation in Trichomycterus iheringi (Eigenmann, 1917) (Siluriformes: Tricomycteridae) from Rio Itatinga and Rio Claro, São Paulo, Brazil. Neotrop. Ichthyol. 8(1): 49-56.

VAN DER LAAN, R., FRICKE, R. \& ESCHMEYER, W.N. (eds). 2019. Eschmeyer's Catalog of Fishes: Classification. http://www. calacademy.org/scientists/catalog-of-fishes-classification/ (last access 13 June 2019).

WHITTAKER, R.J., ARAÚJO, M.B., JEPSON, P., LADLE, R.J., WATSON, J.E.M. \& WILLIS, K.J. 2005. Conservation Biogeography: assessment and prospect. Divers. Distrib. 11(1): 3-23.

WINEMILLER, K.O., AGOSTINHO, A.A. \& CARAMASCHI, E.P. 2008. Fish ecology in tropical streams. In Tropical stream ecology (D. Dudgeon, ed). Academic Press, San Diego, p.107-146.

ZIESLER, R. \& ARDIZZONE, G.D. 1979. The inland waters of Latin America. Copescal Technical Paper No. 1. Food and Agriculture Organization of the United Nations (FAO), Roma, $171 \mathrm{p}$. 